UNITED STATES DEPARTMENT OF THE INTERIOR

GEOLOGICAL SURVEY

NATURE AND ORIGIN OF "VENT GASES" IN THE LASALLE AREA, NORTHEASTERN COLORADO

By

Dudley D. Rice

Charles N. Threlkeld

April Vuletich

Open-File Report 84-220

This report is preliminary and has not been reviewed for conformity with U.S. Geological Survey editorial standards. 
Figure 1.--Diagram showing postulated generation of hydrocarbons with

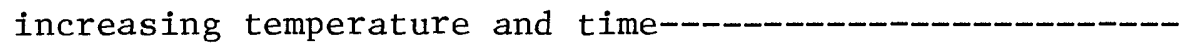

2. Hydrocarbon composition versus methane carbon isotope ratio of natural gas from Wattenberg area, Denver Basin

Table 1. Chemical and isotopic composition of "vent" gas from LaSalle-_-_-_-_-_-_-_-_-

2. Chemical and isotopic composition of gas from nearby oil and gas wells-______-_ 


\section{Nature and Origin of "Vent Gases" in the LaSalle Area,}

Northeastern Colorado

by

Dudley D. Rice

Charles N. Threlkeld

April Vuletich

\section{INTRODUCTION}

Recently, natural gas has been venting to the surface in the town of LaSalle, southern Weld County, Colorado. The gas is believed to be coming up abandoned water wells that may be as much as $335 \mathrm{~m}$ (1100 ft) deep. The gas has reportedly caused explosions in the yard of Wickes Lumber Company and may result in more explosions in the future if the flow of gas from the subsurface continues. Our investigations are aimed at determining the source of the gas. Based on evidence presented below, the gas is interpreted to be of thermogenic origin and to have migrated from deeper, thermally mature rocks.

LaSalle is in the Wattenberg area, which lies along the axis of the Denver Basin. Hydrocarbons are produced in the area from three main reservoirs of Cretaceous age that range in depth from $1220 \mathrm{~m}(4000 \mathrm{ft})$ to $2590 \mathrm{~m}$ (8500 ft).

Natural gas also occurs in ground water of the Upper Cretaceous Laramie-Fox Hills aquifer in the region at depths less than $150 \mathrm{~m}$ (500 ft). Pumping the water to the surface lowers the pressure and causes dissolved gas to come out of solution. If the free gas accumulates in an enclosed area, it can cause an explosion and fire hazard.

Natural gas is formed by two distinct processes. At shallow depths of burial and low temperatures, methane-rich gas is generated during decomposition of organic matter by microorganisms. This gas is formed in environments free of dissolved oxygen and sulfate and is referred to as biogenic gas. 
Natural gas can also be generated by thermal degradation and cracking of kerogen, oil, and other nonhydrocarbon precursors with increasing temperature and advancing geologic time. This type of gas is referred to as thermogenic and probably is the origin of most gas produced from commercial oil and gas fields.

Natural gases can generally be distinguished by their chemical compositions and carbon isotope ratios (Fuex, 1977). Biogenic gas is predominantly methane that is isotopically light $\left(\delta^{13} \mathrm{C}_{1}\right.$ values lighter than $-55 \mathrm{ppt}$ ) because of biological ${ }^{12}$ C-enrichment (Rice and Claypool, 1981). During early and intermediate stages of thermal history, methane generation is accompanied by heavier hydrocarbons, including oil, and is isotopically heavier than biogenic gas $\left({ }^{13} C_{1}\right.$ values are generally heavier than $-50 \mathrm{ppt}$ ) because of smaller kinetic isotope effects associated.with thermal cracking. During late stages of burial history at very high temperatures, natural gas becomes devoid of all heavier hydrocarbons and the isotopic composition of methane approaches that of the original organic matter $\left(\delta^{13} C_{1}\right.$ values are generally heavier than $-35 \mathrm{ppt}$ ).

In order to determine the origin of "vent" gas at LaSalle, natural gas was sampled and analyzed from six sites in the area of Wickes Lumber Company (sec. 31, T. 5 N., R. 65 W.) and from nearby oil and gas wells. Samples were analyzed by the methods described by Claypool and others (1980).

\section{RESULTS AND DISCUSSION}

The analyses are summarized in Tables 1 and 2. The volume percentage of selected components is reported, together with the proportion of methane in the hydrocarbon fraction and the carbon isotope ratio of the methane.

The results of other gas studies in the general area by Rice and Threlkeld (1982) and Rice (1983a) are important in determining the origin of the "vent" gases at LaSalle. Natural gases from water wells near Hudson (secs. 12 and 13, T. 3 N., R. 65 W. $)$ are generally dry $\left(C_{1} / C_{1-5}>0.99\right)$ and enriched in the light isotope ${ }^{12} \mathrm{C}\left(\delta^{13} C_{1}\right.$ values are about $-73 \mathrm{ppt}$ ) (Rice and Threlkeld, 1982). These gases were interpreted to be of biogenic origin and are being or were generated in an anoxic, sulfate-free environment within the aquifer system. 
Natural gases from the Terry and Hygiene Sandstone Members of Pierre Shale, Codell Sandstone Member of Carlile Shale, and "J" sandstone have been sampled and analyzed in the Wattenberg area, which includes LaSalle (Rice, 1983a). These gases, on the basis of chemical and isotopic composition, are interpreted to be of thermogenic origin; that is, the gas was generated during the mature stage of hydrocarbon generation (Fig. 1).

Gases from the Terry and Hygiene Sandstone Members of the Pierre Shale, the youngest reservoirs, are the isotopically lightest $\left(\delta^{13} \mathrm{C}_{1}\right.$ values range from -55.7 to $-47.7 \mathrm{ppt})$ and chemically wettest $\left(\mathrm{C}_{1} / \mathrm{C}_{1-5}\right.$ values range from 0.67 to 0.83) (Fig. 2) and are associated with oil. Because the Pierre Shale is not exceptionally organic-rich and is marginally mature in the area, the oil and gas in the Terry and Hygiene have probably migrated vertically as much as $610 \mathrm{~m}$ (2000 ft) from the thermally mature Greenhorn-Niobrara interval.

Gases from the Codell generally become isotopically heavier $\left(\delta^{13} C_{1}\right.$ values range from -47.8 to $-43.5 \mathrm{ppt})$ as they become chemically drier $\left(\mathrm{C}_{1} / \mathrm{C}_{1-5}\right.$ values range from 0.76 to 0.8 ) (Fig. 2). During the main part of mature stage, oil and associated gas (isotopically lightest and chemically wettest) were generated from Type II kerogen associated with thermally mature marine source rocks, such as those in Greenhorn-Niobrara interval. During the hotter, later part of the stage, wet gas (isotopically heaviest and chemically driest) and condensate were generated from residual kerogen and from heavier hydrocarbons previously generated.

Variations in the character of the gases from the " $J$ " sandstone, the oldest reservoir, are similar to those of the Codell; they become isotopically heavier $\left({ }^{13} \mathrm{C}_{1}\right.$ values range from -47.9 to $-43.1 \mathrm{ppt}$ ) as they become chemically drier $\left(\mathrm{C}_{1} / \mathrm{C}_{1-5}\right.$ values range from 0.84 to 0.87$)$ (Fig. 2). Gases from "J" are interpreted to have been generated at similar levels of maturity as those of the Codell, but from nonmarine (Type III) kerogen closely associated with the reservoirs. These gases are nonassociated and are isotopically heavier and chemically drier at similar levels of maturity than those generated from marine source rocks (Rice, $1983 b)$.

The "vent" gases at LaSalle are chemically wet $\left(\mathrm{C}_{1} / \mathrm{C}_{1-5}\right.$ values of about 0.8$)$ and isotopically heavy $\left({ }^{13} \mathrm{C}_{1}\right.$ values of about $-44 \mathrm{ppt}$ ) (Table 1 ), and are interpreted 
to be of thermogenic origin. The gases are almost identical in compositon to those produced from the underlying Code11 Sandstone Member in the immediate area and in the Wattenberg area (Tables 1 and 2; Fig. 2). The only exception is that the gas from the Dabco No. 2 well has as much as $20 \% \mathrm{CO}_{2}$ (Fig. 2). The $\mathrm{CO}_{2}$ was probably added to the well during its recent hydraulic stimulation required to provide economic flow rates.

In conclusion, the "vent" gases at LaSalle are almost identical in both chemical and isotopic compostion to those produced from the Codell Sandstone Member of Carlile Shale at depths of about $2130 \mathrm{~m}$ (7000 ft). The gas was probably generated from thermally mature marine source rocks (Type II kerogen) in the GreenhornNiobrara interval and has subsequently migrated to the surface. At this time, we do not have data to determine if this gas migration is a natural phenomenon or is related to drilling activity in the area. 
Claypoo1, G. E., Threlkeld, C. N., and Magoon, L. B., 1980, Biogenic and thermogenic origins of natural gas in the Cook Inlet Basin: American Associated of Petroleum Geologists Bulletin, v. 64, p. 1131-1139.

Fuex, A. N., 1977, The use of stable carbon isotopes in hydrocarbon exploration: Journal of Geochemical Exploration, v. 7, p. 155-188.

Rice, D. D., 1983a, Application of organic geochemistry to hydrocarbon occurrence, in Patterns of sedimentation, diagenesis, and hydrocarbon accumulation in Cretaceous rocks of the Rocky Mountains: Society of Economic Paleontologists and Mineralogists Short Course Notes No. 11, p. 61 to 6-41.

1983b, The relation of natural gas composition to thermal maturity and source-rock type in the San Juan Basin, northwestern New Mexico and southwestern Colorado: American Association of Petroleum Geologists Bulletin, v. 67 , p. 1199-1218.

Rice, D. D., and Claypool, G. E., 1981, Generation, accumulation, and resource potential of biogenic gas: American Association of Petroleum Geologists Bulletin, v. 65, p. 5-25.

Rice, D. D., and Threlkeld, C. N., 1982, Occurrence and origin of natural gas in ground water, southern Weld County, Colorado: U.S. Geological Survey Open-File Report 82-496, 6 p. 


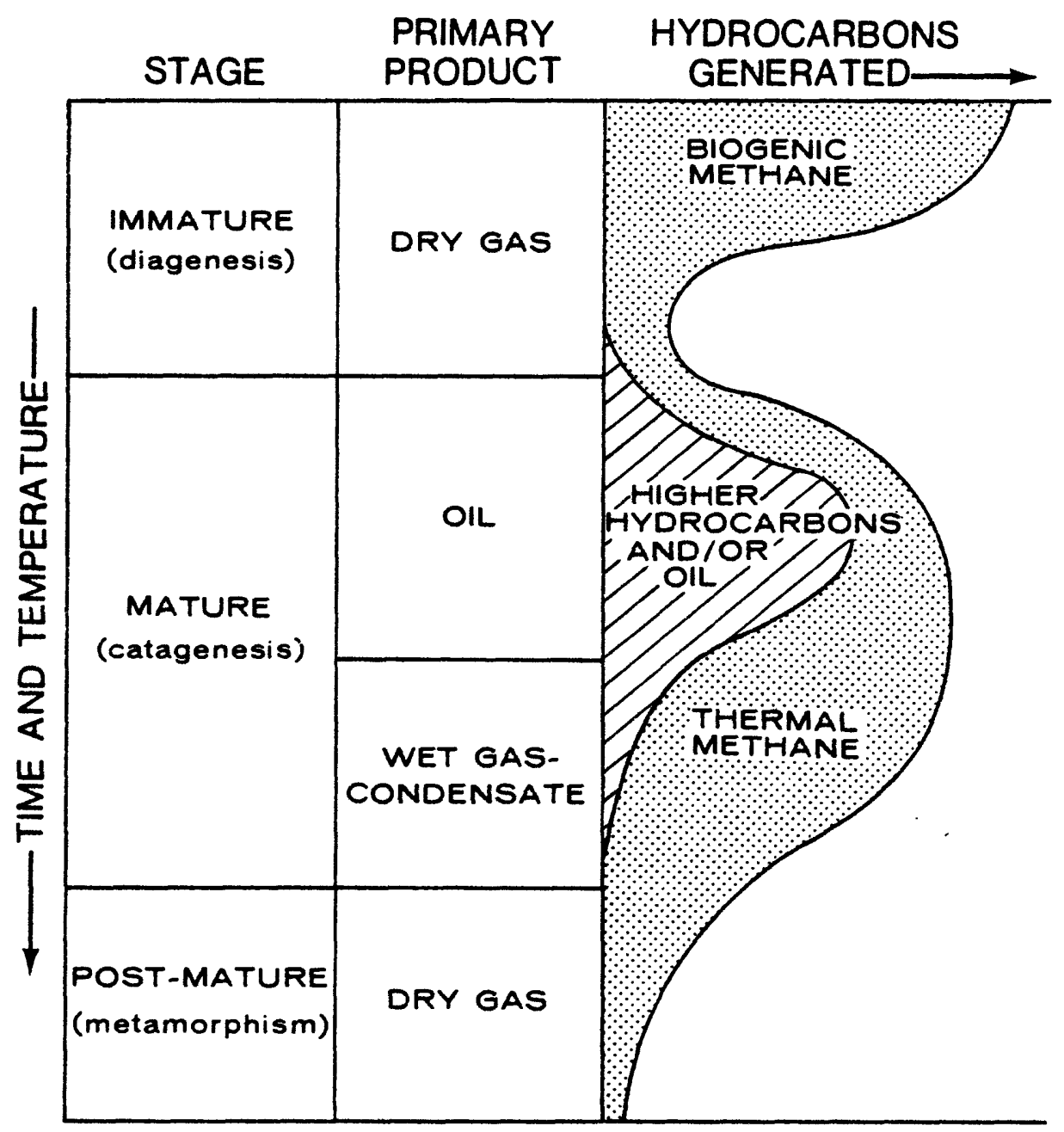

Figure 1. Diagram showing postulated generation of hydrocarbons with increasing temperature and time. 


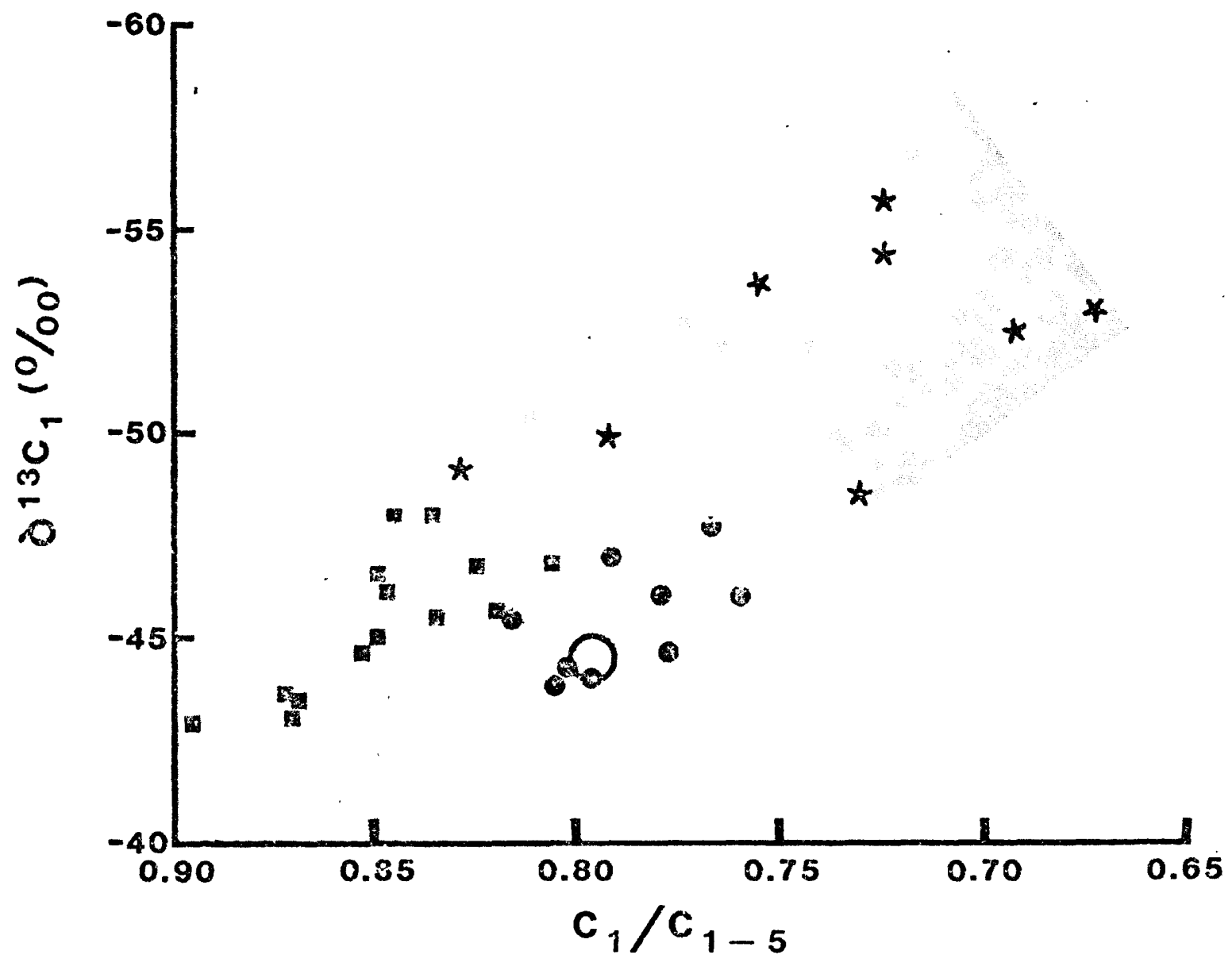

Figure 2. Hydrocarbon composition versus methane carbon isotope ratio of natural gas from Wattenberg area, Denver Basin. Stars indicate gas samples from Terry and Hygiene Sandstone Members, Pierre Shale; dots from Codell Sandstone Member, Carlile Shale; squares from " $J$ " sandstone. Circle indicates "vent" gases from LaSalle. 


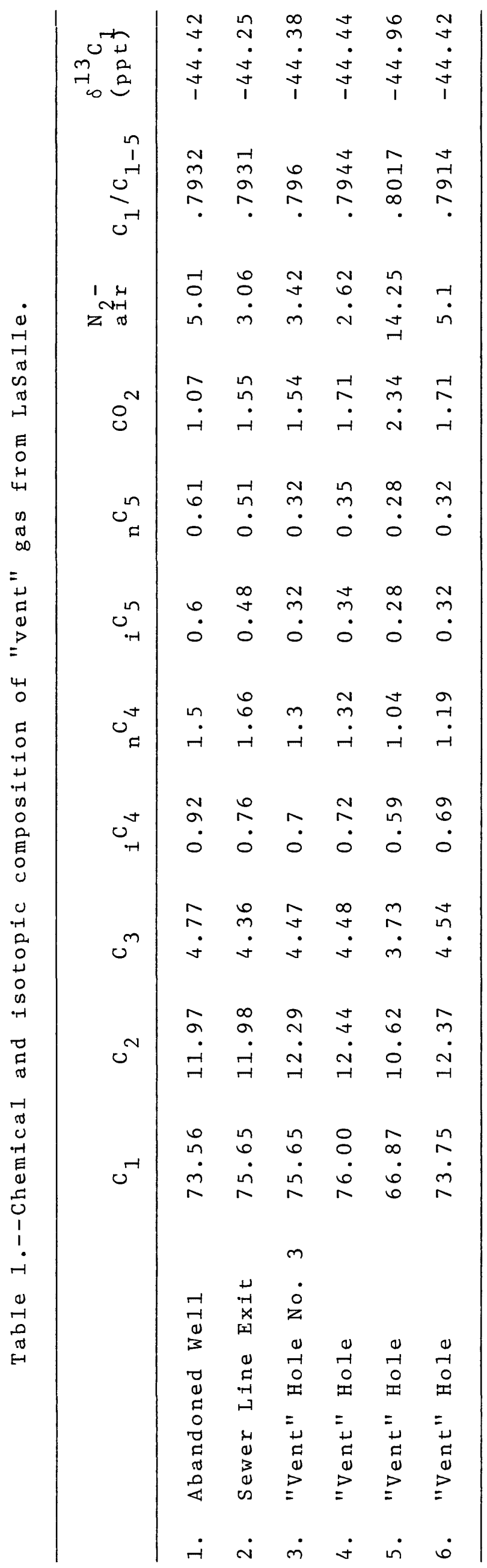




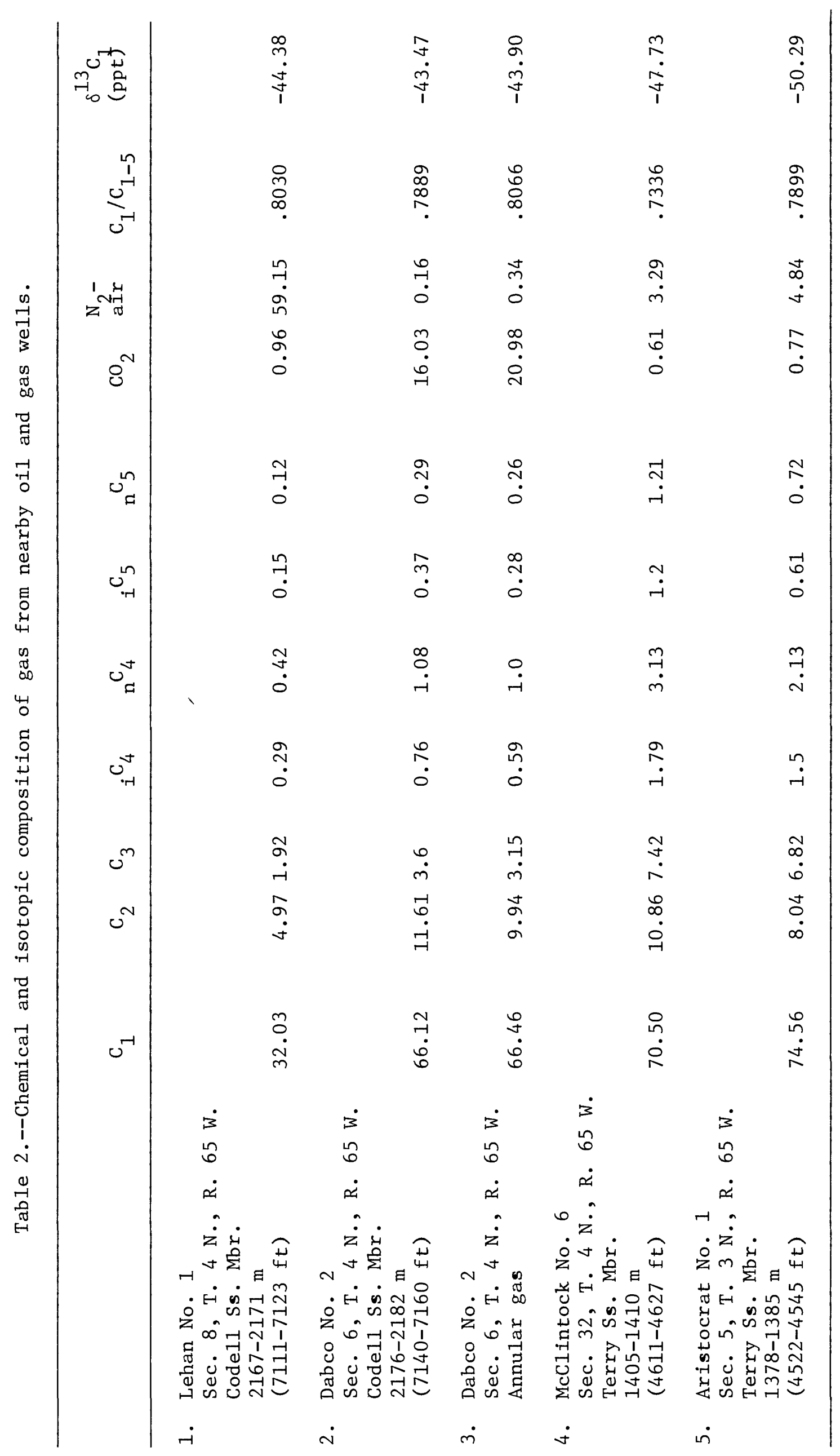

